\title{
AKRUAL
}

Jurnal Akuntansi

http://fe.unesa.ac.id/ojs/index.php/akrl

\section{PENGARUH STRUKTUR AKTIVA, PROFITABILITAS, KEBIJAKAN DIVIDEN TERHADAP STRUKTUR MODAL PADA PERBANKAN YANG TERDAFTAR DI BURSA EFEK INDONESIA PADA TAHUN 2005-2009}

\author{
Gita Cahya Puspita \\ Fakultas Ekonomi Universitas Negeri Surabaya \\ Email: puzphit@yahoo.com \\ Rohmawati Kusumaningtias \\ Fakultas Ekonomi Universitas Negeri Surabaya \\ Email: rohmawatikusnitia@yahoo.co.id \\ Artikel diterima: 4 Januari 2010 \\ Revisi terakhir: 10 Maret 2010
}

\begin{abstract}
Banking capital structure has an important role in running a business to run the operations. Given the many factors that affect the company's capital structure research will examine the influence of asset structure, profitability and dividend policy on capital structure in corporate banking. The purpose of this study is to investigate and examine the effect of asset structure, profitability, dividend policy and capital structure of banks listed on the Indonesia Stock Exchange (BEI) in the period 2005 to 2009. The samples used were 7 banking company, where the method used was purposive sampling. Analysis of test data using multiple linear regression. The results indicate that simultaneously asset structure, profitability and dividend policy affects capital structure. While partially variables that affect the capital structure is the structure of assets and profitability, while the partial dividend policy variables do not affect the capital structure.
\end{abstract}

Keywords: banking, capital structure, asset structure, profitability, dividend policy.

\section{PENDAHULUAN}

\section{Latar Belakang}

Perbankan merupakan badan usaha yang bertugas sebagai penghimpun dana dari masyarakat dalam bentuk simpanan dan menyalurkannya kembali dalam bentuk kredit. Untuk dapat memberikan pelayanan di bidang jasa keuangan, bank tentu memerlukan dana. Pendapatan dana bank ini bisa berasal dari dua sumber yaitu sumber internal dan sumber eksternal. Menurut Dendawijaya (2003), Dana yang bersumber dari internal adalah dana yang diperoleh dari dalam bank (modal sendiri), antara lain setoran modal dari pemegang saham, cadangan laba, dan laba yang belum dibagi. Sedangkan dana yang bersumber dari eksternal adalah dana yang diperoleh 
dari luar bank, bisa berasal dari masyarakat atau lembaga lainnya. Dana bank yang berasal dari masyarakat luas diperoleh dari simpanan masyarakat yang berupa giro, tabungan dan deposito. Sedangkan dana yang bersumber dari lembaga lain antara lain berupa Bantuan Likuiditas Bank Indonesia (BLBI) dan pinjaman antar bank.

Menurut Riyanto (2001), struktur modal merupakan suatu pembelanjaan permanen yang mencerminkan perimbangan antara kewajiban jangka panjang dengan modal sendiri. Sriwulansari (2009) mengemukakan, semakin besar proporsi kewajiban pada struktur modal suatu perusahaan, mengakibatkan semakin tinggi beban tetap dan komitmen pembayaran kembali yang ditimbulkan. Kemungkinan perusahaan tidak mampu membayar bunga dan pokok pinjaman saat jatuh tempo dan kemungkinan kerugian kreditur juga meningkat. Hal ini tentunya akan menghambat perkembangan perusahaan dan pada akhirnya membuat calon investor berpikir dua kali untuk menanamkan modalnya di perusahaan tersebut. Bagi suatu perusahaan, struktur modal yang optimal merupakan keputusan keuangan penting yang mempengaruhi kinerja dan nilai perusahaan. Menurut Brigham dan Houston (2001), kinerja perusahaan yang bagus mengakibatkan harga sahamnya naik di pasar modal, sehingga kemakmuran pemilik perusahaan dapat tercapai. Struktur modal pada penelitian ini menggunakan perhitungan leverage yang diproksikan dengan Debt Equity Ratio yaitu membandingkan total hutang dengan total ekuitas. Semakin tinggi debt equity ratio semakin besar jumlah modal pinjaman yang digunakan dalam menghasilkan keuntungan bagi perusahaan. Dendawijaya (2001) menyatakan bahwa sumber pendanaan pada perbankan lebih banyak diambil dari dana pihak ketiga yang berupa tabungan, giro dan deposito. Dana pihak ketiga dapat mencapai 80\%-90\% dari seluruh dana yang dikelola oleh bank.

Berdasarkan tabel 1. selama tahun 2005-2009 jumlah aktiva selama periode tahun tersebut mengalami kenaikan yang signifikan, secara berturut-turut, aktiva mengalami kenaikan $19,8 \% ; 3,37 \% ; 19,31 \% ; 13,78 \%$. Kenaikan aktiva seharusnya diikuti oleh kenaikan hutang, namun pada tahun 2007 mengalami penurunan sebesar $-0,11 \%$. Hal ini dapat diangkat permasalahan yang membuat penulis tertarik untuk meneliti penyebab penurunan hutang di tahun 2007 dan menjelaskan pada tahun yang sama pada sisi aktiva mengalami kenaikan dari namun pada sisi hutang mengalami.

Tabel 1. Jumlah aktiva dan hutang pada tahun 2005-2009

\begin{tabular}{lccccc}
\hline & $\mathbf{2 0 0 5}$ & $\mathbf{2 0 0 6}$ & $\mathbf{2 0 0 7}$ & $\mathbf{2 0 0 8}$ & $\mathbf{2 0 0 9}$ \\
\hline Aktiva & 177.377 & 212.499 & 219.653 & 262.061 & 298.180 \\
Hutang & 156.651 & 184.826 & 184.617 & 232.170 & 258.311 \\
\hline
\end{tabular}

Sumber: Statistik Perbankan Indonesia (diolah)

Menurut Swastha (2002), struktur aktiva mempunyai dua bagian yaitu aktiva lancar sebagai pembiayaan jangka pendek dan aktiva tetap sebagai pembiayaan jangka. Peneliti menggunakan faktor struktur aktiva dalam penelitian ini karena 
mempunyai peranan penting dalam pembiayaan perbankan. Aktiva tetap dapat dijadikan jaminan ketika perusahaan ingin menjaminkan dana kepada kreditur. Ini sesuai dengan pendapat Brigham dan Houston (2001) yang menyatakan bahwa perusahaan yang memiliki aktiva tetap dapat digunakan oleh banyak perusahaan sebagai jaminan yang baik. Dengan semakin besar aktiva tetap yang dimiliki perusahaan, jaminan untuk meminjam dana juga semakin besar dan pada akhirnya meningkatkan penggunaan kewajiban. Dalam penelitian Amidu (2007) dan penelitian Gaud (2003) meyatakan bahwa struktur aktiva berpengaruh positif terhadap struktur modal. Semakin tinggi struktur aktiva maka semakin tinggi pula struktur modal, begitu pula sebaliknya semakin rendah struktur aktiva akan semakin rendah pula struktur modal. Hasil penelitian Hassa (2008) mengatakan bahwa struktur aktiva berpengaruh negatif terhadap struktur modal. Dengan adanya research gap tersebut, peneliti ingin melakukan penelitian lanjutan antara struktur aktiva terhadap struktur modal.

Semakin profitabel suatu perusahaan maka akan semakin besar laba yang dihasilkan, begitu pula laba ditahannya juga akan semakin besar sehingga perusahaan dapat menggunakannya untuk memenuhi kebutuhan dananya. Karena itu perusahaan akan cenderung mengurangi penggunaan kewajiban ketika profitabilitasnya tinggi. Peneliti menggunakan variabel profitabilitas karena profitabilitas dapat mempengaruhi struktur modal, apabila industri perbankan mendapatkan profit yang tinggi maka penggunaan struktur modal akan berkurang dan sebaliknya jika profitnya turun maka penggunaan struktur modal akan tinggi. Dalam penelitian ini, profitabilitas diukur dengan return on assets (ROA), ROA merupakan ukuran dari kinerja keuangan bank dalam memperoleh laba sebelum pajak, yang dihasilkan dari total asset (total aktiva) bank yang bersangkutan. Menurut Husnan (1995), semakin besar ROA menunjukkan kinerja bank semakin baik, karena tingkat pengembalian (return) semakin besar. Menurut Atmaja (2008), Return On Assets (ROA) dapat menunjukkan kinerja keuangan perusahaan atas aktiva yang telah digunakan. Kelebihan-kelebihan lain dari digunakannya ROA yaitu: (a) Mendorong manajer untuk memfokuskan pada hubungan antara penjualan, beban dan investasi, (b) ROA digunakan Bank Indonesia untuk menilai kesehan bank, (c) ROA menunjukan kemampuan bank dalam menggunakan sumber-sumber investasi riil, (d) Fokus pada efisiensi biaya, (e) Memungkinkan perbandingan kinerja antar devisi meskipun skala kegiatan usaha devisi dan bidang bisnisnya berbeda. 


\section{ROA}

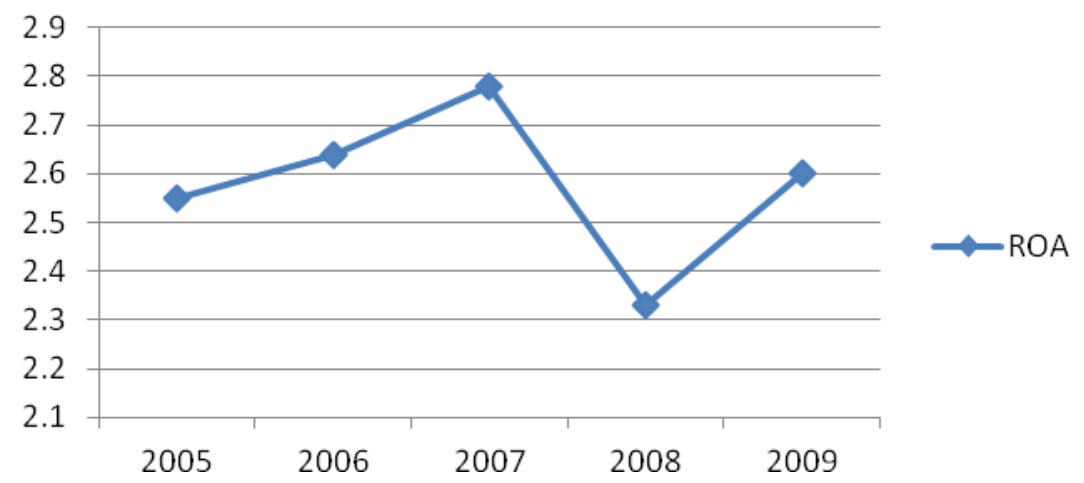

Sumber: Statistik Perbankan Indonesia (2009)

\section{Gambar 1. Return of Assets (ROA)}

Pada tahun 2005 hingga tahun 2007 ROA mengalami kenaikan yang signifikan namun pada tahun 2008 keuntungan perbankan yang diproksikan dengan ROA mengalami penurunan yang drastis, hal ini disebabkan karena pada tahun tersebut terjadi krisis global yang mengakibatkan penurunan laba. Hasil penelitian Kusuma (2005) berpendapat bahwa profitabilitas berpengaruh positif pada struktur modal sedangkan dalam penelitian Hapsari (2010) dan Amidu (2007) berpendapat bahwa profitabilitas berpengaruh negatif signifikan terhadap struktur modal.

Kebijakan dividen adalah pembagian keuntungan bagi para pemegang saham. Menurut West \& Copeland (1997), kebijakan dividen merupakan pembagian laba antara pembayaran kepada pemegang saham dan investasi kembali perusahaan. Laba ditahan (retained earnings) merupakan salah satu sumber dana paling penting untuk membiayai pertumbuhan perusahaan, tetapi dividen merupakan arus kas yang disisihkan untuk pemegang saham. Dalam hal ini alat ukur yang digunakan untuk dividen adalah dividend payout ratio yang merupakan perbandingan antara dividen per lembar saham dengan laba per lembar saham.

Sriwulansari (2009) menyatakan ketika perusahaan membagikan dividen, hal ini akan mengurangi besarnya laba ditahan. Semakin besar dividen yang dibagikan kepada pemegang saham akan mengakibatkan semakin berkurangnya laba ditahan sehingga untuk membiayai kebutuhan dananya, perusahaan membutuhkan dana eksternal (penerbitan hutang dan saham). Dalam penelitian Nurfauziah (2007) mengatakan bahwa kebijakan dividen berhubungan negatif, namun berbeda dengan Soesetio (2008) mengatakan bahwa kebijakan dividen berpengaruh positif. Dengan adanya research gap dari penelitian sebelumnya maka peneliti akan melakukan penelitian lanjutan.

Dalam penelitian ini yang digunakan adalah tahun 2005-2009. Berdasarkan Infobank (Juni 2006 dalam Agustina 2004), pada tahun 2005 perekonomian 
Indonesia mengalami kondisi perekonomian global yang kurang menguntungkan mengakibatkan laba perbankan mengalami penurunan $-23,56 \%$ sedangkan pada tahun 2008. Terjadi krisis keuangan global yang berpengaruh terhadap perekonomian seluruh dunia termasuk Indonesia, berpotensi menurunkan kemampuan dan keinginan bank memberikan kredit, mempersulit bank dalam mempertahankan kualitas aset, menurunkan profitabilitas, dan mengurangi kecukupan modal bank untuk menjamin kesinambungan operasional.

Berdasarkan uraian latar belakang maka perumusan masalah sebagai berikut:

1. Apakah struktur aktiva, profitabilitas, dan kebijakan deviden berpengaruh terhadap struktur modal secara simultan?

2. Apakah struktur aktiva, profitabilitas, dan kebijakan deviden berpengaruh terhadap struktur modal secara parsial?

\section{KAJIAN PUSTAKA \\ Struktur Modal}

Struktur modal merupakan faktor yang sangat berpengaruh dalam menjalankan operasional suatu usaha. Setiap perusahaan dalam menjalankan operasionalnya tidak akan lepas dari permasalahan pendanaan. Pendanaan yang diperoleh dari perusahaan dapat diperoleh dari modal sendiri (ekuitas) dan juga dapat diperoleh dari pihak eksternal (hutang).

Menurut ikatan Akuntansi Indonesia (1997 dalam Khomariyah 2007) struktur modal adalah penentuan kebijakan struktur keuangan akan terkait dengan struktur modal. Struktur modal dalam perusahaan berkaitan erat dengan investasi sehingga dalam hal ini akan menyangkut sumber dana yang akan digunakan untuk membiyai proyek investasi tersebut. Sumber dana tersebut pada dasarnya terdiri dari penerbitan saham (equity financing), penerbit obligasi (debt financing) dan laba ditahan (retained earning).

Menurut Riyanto (2001) struktur modal adalah perbandingan antara jumlah hutang jangka panjang dengan modal sendiri (ekuitas). Sementara menurut Brigham dan Houston (2006) kebijakan struktur modal melibatkan adanya suatu pertukaran antara resiko dan pengembalian, penggunaan lebih banyak hutang akan meningkatkan resiko yang ditanggung oleh para pemegang saham. Namun penggunaan hutang yang lebih besar biasanya akan menyebabkan terjadinya ekspektasi tingkat pengembalian atas ekuitas yang lebih tinggi. Oleh karena itu struktur modal yang optimal harus mencapai suatu keseimbangan antara resiko dan pengembalian sehingga dapat memaksimalkan nilai perusahaan.

Dalam penelitian ini perhitungan menggunakan leverage yang proxikan dengan Debt Equity Ratio (DER). Sudana (2009) debt equity ratio (DER) merupakan kemampuan perusahaan dalam membayar hutang dengan modal yang dimilikinya dan sangat berkaitan dengan penciptaan suatu struktur modal yang dapat mempengaruhi kebijakan pendanaan perusahaan yang tepat guna memaksimalkan nilai perusahaan. 
Rasio ini mengukur besar kecilnya penggunaan hutang dibandingkan dengan modal sendiri. Dirumuskan :

$$
\text { Debt Equity Ratio }=\frac{\text { Total debt }}{\text { Total equity }}
$$

\section{Struktur Aktiva}

Struktur aktiva terdiri dari dua bagian yaitu aktiva lancar dan aktiva tetap. Aktiva lancar (current assets) adalah uang kas dan aktiva lainnya yang dapat diharapkan untuk dicairkan atau ditukarkan menjadi uang tunai, dijual atau dikonsumsi dalam periode berikutnya, paling lama satu tahun dalam perputaran kegiatan perusahaan yang normal (Munawir, 2002 dalam Elisa 2007).

Menurut Fransisko (2005 dalam prima 2007), aktiva tetap adalah kekayaan yang dimiliki perusahaan yang secara fisik tampak dan turut berperan dalam operasi perusahaan secara permanen, selain itu mempunyai umur ekonomis lebih dari satu periode dalam kegiatan perusahaan seperti tanah, gedung, mesin, peralatan kantor, kendaraan. Struktur aktiva mempunyai peranan penting dalam menjalankan operasional perusahaan karena struktur aktiva sebagai pembiayaan operasional perbankan, struktur aktiva tersebut terdapat pada neraca sebelah debet.

Struktur aktiva dapat dipandang dari objek operasional yang pada dasarnya menggolongkan aktiva dalam perbandingan tertentu untuk keperluan operasi utama perusahaan. Untuk keperluan ini, struktur aktiva dapat dipandang dari dua sisi yaitu aktiva yang harus tersedia untuk beroperasi perusahaan selama periode berlangsung atau disebut dengan aktiva lancar serta aktiva yang harus disediakan untuk operasional perusahaan untuk jangka panjang atau disebut dengan aktiva tetap.

Riyanto (2001), struktur aktiva adalah perbandingan atau perimbangan antara aktiva lancar dan aktiva tetap, dengan rumuskan sebagai berikut:

Total Aktiva lancar

\section{Profitabilit:}

Total Aktiva tetap

Sudana (2009), Profitabilitas adalah kemampuan suatu bank untuk menghasilkan laba dengan menggunkan sumber-sumber yang dmiliki oleh perusahaan. Sedangkan menurut Dendawijaya (2003), profitabilitas bank adalah tingkat efisiensi usaha yang dicapai oleh bank tersebut. Dalam penelitian ini, profitabilitas diukur dengan return on assets (ROA), ROA merupakan ukuran dari kinerja keuangan bank dalam memperoleh laba sebelum pajak, yang dihasilkan dari total asset (total aktiva) bank yang bersangkutan. Menurut Husnan (1995), semakin besar ROA menunjukkan kinerja bank semakin baik, karena tingkat pengembalian (return) semakin besar. Menurut Atmaja (2008), Return On Assets (ROA) dapat menunjukkan kinerja keuangan perusahaan atas aktiva yang telah digunakan.

Menurut Agustina (2007), ROA Merupakan rasio yang digunakan untuk mengukur kemampuan manajemen bank dalam memperoleh keuntungan secara keseluruhan. Sedangkan menurut Sudana (2009), ROA adalah kemampuan 
perusahaan dengan menggunakan seluruh aktiva yang dimiliki untuk menghasilkan laba setelah pajak. Rasio ini digunakan untuk mengukur kemampuan manajemen bank dalam memperoleh keuntungan (laba) secara keseluruhan. Dapat dirumuskan sebagai berikut :

$$
\text { ROA }=\frac{\text { Laba setelah pajak }}{\text { Total aktiva }} \times 100 \%
$$

Dendawijaya (2003) semakin besar ROA suatu bank, semakin besar pula tingkat keuntungan yang dicapai bank dan semakin baik pula posisi bank tersebut dari segi penggunaan asset. Dalam penelitian ini ROA digunakan sebagai alat untuk mengukur profitabilitas perbankan. Bank Indonesia lebih mementingkan penilaian besarnya ROA karena bank Indonesia sebagai Pembina dan pengawas perbankan, lebih mengutamakan nilai profitabilitas suatu bank yang diukur dengan asset yang dananya sebgian besar berasal dari dana simpanan masyarakat.

\section{Kebijakan Deviden}

Menurut Weston \& Coopeland (1997), kebijakan dividen merupakan pembagian laba antara pembayaran kepada pemegang saham dan investasi kembali perusahaan. Laba ditahan (retained earnings) merupakan salah satu sumber dana paling penting untuk membiayai pertumbuhan perusahaan, tetapi dividen merupakan arus kas yang disisihkan untuk pemegang saham. Kebijakan deviden adalah pembagian keuntungan bagi para pemegang saham. Menurut Riyanto (1993) kebijakan deviden adalah pembagian pendapatan (earning) antara penggunaan pendapatan untuk dibayarkan kepada para pemegang saham sebagai deviden atau untuk digunakan di dalam perusahaan, yang berarti pendapatan tersebut harus ditahan di dalam perusahaan atau disebut laba ditahan.

Menurut Atmaja (2008) kebijakan dividen adalah pembuatan keputusan seorang manajer dalam membagikan laba bersih perusahaan. Manajemen mempunyai dua alternatif dalam membagikan laba bersih setelah pajak yaitu:

1. Dibagi kepada para pemegang saham perusahaan dalam bentuk dividen

2. Diinvestasikan kembali keperusahaan sebagai laba ditahan (retained earning)

Di dalam penelitian ini rasio yang digunakan untuk mengukur kebijakan deviden adalah dividend payout ratio. Riyanto (1993), Persentase dari pendapatan yang akan dibayarkan kepada pemegang saham sebagai cash dividends disebut dividend payout ratio. Atmaja (2008) persentase dividen yang dibagi dari EAT (Earning After Tax) disebut Dividend Payout Ratio (DPR), dapat dirumuskan sebagai berikut:

$$
\mathrm{DPR}=\frac{\text { dividend per } \text { share }}{\text { earning per share }}
$$




\section{Hubungan Variabel-Variabel terhadp Struktur Modal}

\section{a. Struktur Aktiva}

Struktur aktiva terdiri dari aktiva lancar dan aktiva tetap. Aktiva lancar digunakan untuk pembiayaan jangka pendek periode kurang dari dua belas bulan atau satu tahun sedangkan aktiva tetap atau aktiva berwujud digunakan untuk pembiayaan jangka panjang biasanya digunakan untuk jaminan bagi debitur, periode penggunaan relatif lebih lama lebih dari duabelas bulan atau satu tahun. Semakin tinggi struktur aktiva maka semakin tinggi struktur modalnya. Sebaliknya semakin rendah struktur aktiva maka semakin rendah kemampuan dari perusahaan tersebut untuk menjamin hutang jangka panjangnya (Sriwulansari, 2009).

\section{b. Profitabilitas}

Profitabilitas adalah kemampuan perusahaan dalam menghasilkan laba. Profitabilitas suatu perusahaan menunjukkan perbandingan antara laba dengan aktiva atau modal yang menghasilkan laba tersebut. Dengan kata lain profitabilitas adalah kemampuan perusahaan untuk menghasilkan laba selama periode tertentu (Riyanto, 2001)

Perusahaan yang memiliki profitabilitas tinggi cenderung menggunakan hutang relatif kecil karena laba ditahan yang tinggi sudah memadai untuk membiayai sebagian besar kebutuhan pendanaan. Perusahaan dengan tingkat pengembalian yang tinggi atas investasi menggunakan hutang yang relatif kecil karena tingkat pengembalian tinggi memungkinkan perusahaan untuk membiayai sebagian besar pendanaan dengan dana internal. Semakin tinggi profitabilitas maka semakin rendah hutang dengan pihak luar, karena tingkat keuntungan yang tinggi memungkinkan perusahaan untuk memperoleh sebagian besar pendanaannya dari laba ditahan. Hal ini akan berpengaruh terhadap penentuan komposisi struktur modal (Sriwulansari, 2009)

\section{c. Kebijakan Dividen}

Kebijakan dividen adalah keputusan seorang manajer untuk menentukan laba yang diperoleh perusahaan akan dibagikan kepada pemegang saham sebagai dividen atau akan ditahan dalam bentuk laba ditahan guna pembiayaan investasi di masa mendatang.

Dividen merupakan laba bersih yang dibagikan kepada para pemegang saham (pemilik modal). Selain untuk dibagikan sebagai dividen, laba bersih ditahan di dalam perusahaan untuk membiayai kegiatan operasi selanjutnya, yang disebut sebagai laba ditahan (retained earning). Dividen yang dibagikan kepada para pemegang saham dapat diukur dengan menggunkan dividend payout ratio yang merupakan perbandingan antara dividen per lembar saham dengan laba per lembar saham (Van Horne dan Wachowicz, 1998).

Hubungan dividend payout ratio dengan struktur modal, apabila dividend payout ratio tinggi maka jumlah laba bersih yang akan ditahan sebagai laba ditahan (retained earning) akan berkurang sehingga sumber pembiayaan internal perusahaan 
akan semakin kecil dan perusahaan akan mencari sumber dana yang berasal dari eksternal.

\section{METODE PENELITIAN}

Analisis data dilakukan menggunakan regresi linier berganda dengan menggunakan variabel terikat adalah sturuktur modal (DER) dan variabel bebas berupa struktur aktiva (total aktiva lancar dibagi dengan total aktiva tetap), profitabilitas (ROA), serta kebijakan dividen (divident payout ratio). Populasi yang digunakan dalam penelitian ini adalah industri perbankan yang telah terdaftar di Bursa Efek Indonesia (BEI) pada tahun 2005-2009. Sampel dalam penelitian ini mengunakan teknik purposive sampling. Sugiyono (2009), Purposive sampling adalah teknik sampling yang digunakan peneliti dengan adanya pertimbanganpertimbangan tertentu didalam pengambilan sampel. Kriteria dalam pemilihan sampel pada penelitian ini adalah:

1. Industri perbankan yang terdaftar di Bursa Efek Indonesia (BEI).

2. Mengeluarkan laporan keuangan pada tahun 2005-2009.

3. Membagikan dividen lima tahun beruturut-turut selama tahun penelitian.

Industri perbankan yang terdaftar di Bursa Efek Indonesia (BEI) berjumlah dua puluh sembilan perusahaan sedangkan jumlah perbankan yang tidak membagikan dividen selam lima tahun berturut-turut pada tahun penelitian sebanyak dua puluh dua perbankan sehingga jumlah sampel penelitian adalah tujuh perbankan yang terdaftar di Bursa Efek Indonesia (BEI), yaitu: Bank Negara Indonesia (BBNI), Bank Rakyat Indonesia (BBRI), Bank Central Asia (BCA), Bank Mandiri (BMRI), Bank Danamon $(\mathrm{BDMN})$, Bank Internasional Indonesia (BNII), dan Bank CIMB Niaga (BNGA).

\section{HASIL DAN PEMBAHASAN \\ Pengaruh Struktur Aktiva, Profitabilitas, Kebijakan Dividen Terhadap Struktur Modal}

Hasil analisis data menunjukkan bahwa struktur aktiva, profitabilitas, kebijakan dividen secara bersama-sama berpengaruh terhadap struktur modal. Hal tersebut berarti kenaikan atau penurunan struktur aktiva, profitabilitas dan kebijakan dividen akan mempengaruhi struktur modal pada industri perbankan di Bursa Efek Indonesia. Dengan demikian hasil penelitian ini mendukung beberapa penelitian sebelumnya seperti penelitian yang dilakukan Soesetio (2008) yang mengatakan bahwa sturktur aktiva, profitabilitas dan kebijakan dividen secara bersama-sama berpengaruh terhadap struktur modal yang diproksikan dengan DER. Perbankan yang besar akan cenderung melakukan hutang kepada pihak ketiga. Hal ini juga sesuai dengan teori Brigham dan Houston (2001) yang menyatakan bahwa ada beberapa faktor-faktor yang mempengaruhi pengabilan keputusan struktur modal beberapa diantaranya adalah struktur aktiva dan profitabilitas. Sedangkan menurut Husnan (2006) kebijakan dividen mempengaruhi struktur modal.

Struktur aktiva berpengaruh terhadap struktur modal, karena struktur aktiva merupakan bagian terpenting dalam membiayai operasional perbankan. Pada 
kenyataannya struktur aktiva yang terdiri dari aktiva lancar dan aktiva tetap merupakan sumber dana kekayaan perbankan yang berada disisi kiri neraca perbankan. Pada industri perbankan aktiva lancar merupakan hal yang terpening dalam menjalankan kegiatan operasional perbankan karena dalam industri perbankan berbeda dengan perusahaan lainnya dimana aktiva lancarnya dapat mencapai $80 \%$ 90\% dari seluruh dana yang dikelola oleh bank. Hal ini dapat dilihat pada fenomena perbankan dimana total asset selama periode penelitian dari tahun 2005-2009 selalu mengalami peningkatan. Hal ini dapat disebabkan karena tingginya kredit yang diberikan kepada masyarakat. Sehingga dapat menyebabkan tingginya aktiva lancar bagi perbankan. Semakin tinggi struktur aktiva yang dimiliki suatu perusahaan perbankan maka hutang pun juga semakin tinggi. Selanjutnya, profitabilitas berpengaruh terhadap struktur modal.

Profit adalah laba atau keuntungan yang dihasilkan oleh suatu perusahaan. Setiap perusahaan pasti menginginkan laba atau keutungan dari hasil operasionanya. Profit yang tinggi akan mempengaruhi hutang suatu perusahaan karena dengan memiliki laba atau keuntungan yang tinggi maka perbankan tidak perlu menggunakan hutang dalam membiayai asset perusahaan perbankan terebut dalam menjalankan operasionalnya. Hal ini seperti pada perusahaan perbankan yang secara umum banyak menggunakan laba ditahannya untuk menjalankan kegiatan usahanya sehingga kurang dalam menggunakan hutang. Kebijakan dividen berpengaruh terhadap struktur modal, kebijakan dividen adalah kebijakan seorang manajer keuangan dalam membagi keuntuungan yang dihasilkan perusahaan, apakah keuntungan tersebut dibagikan sebagai dividen bagi para pemgang saham atau akan dialokasikan sebagai laba ditahan untuk reinvestasi perusahaan. Bagi perusahaan yang telah go public, para investor pasti menginginkan pembagian dividen dari perusahaan karena pembagian dividen yang tinggi akan menggambarkan kesehatan atau nilai dari perusahaan perbankan tersebut. semakin tinggi perusahaan membayarkan dividen para pemegang saham atau investor maka penggunaan hutang akan semakin rendah. Dengan demikian maka faktor di atas merupakan faktor penting yang terdapat di dalam perusahaan perbankan dan perlu untuk dipertimbangkan oleh manajer perusahaan dalam memutuskan struktur modalnya.

\section{Pengaruh Struktur Aktiva Terhadap Struktur Modal}

Berdasarkan hasil analisis data diketahui bahwa struktur aktiva berpengaruh secara parsial terhadap struktur modal. Struktur aktiva mempunyai pengaruh yang positif terhadap struktur modal, berarti kenaikan struktur aktiva perbankan akan diikuti dengan peningkatan struktur modal, kenaikan total aktiva lancar pada perusahaan perbankan akan diikuti oleh total hutang perbankan. Pada tahun 2005 dana pihak ketiga sebesar 1.127.937, pada tahun 2006 meningkat sebesar 1.297.102, pada tahun 2007 sebesar 1.510.934, pada tahun 2008 sebesar 1.753.292, dan pada tahun 2009 meningkat menjadi sebesar 1.973.042. Hal ini menunjukkan bahwa sebagian besar pendanaan dari perbankan didapat dari dana pihak ketiga dimana bagi perbankan merupakan pinjaman atau hutang. Dana pihak ketiga ini dapat berupa 
tabungan, giro dan deposito. Semakin banyak deposan yang menabung atau menyimpan dananya ke perbankan maka hutang bagi perbankan akan meningkat pula karena bank akan mengembalikan dana simpanan dari masyarakat sewaktu-waktu pada saat deposan ingin mengambil dananya kembali sehingga bank harus memiliki aktiva lancar sebesar $80 \%$ - 90\% dari seluruh dana yang dikelola oleh bank. Hasil penelitian ini didukung oleh penelitian Gaud (2003) dan Amidu (2007) yang mengatakan bahwa struktur aktiva berpengaruh positif terhadap struktur modal namun penelitian ini tidak sesuai dengan penelitian Hassa (2008) yang mengatakan bahwa struktur aktiva berpengaruh negatif. Selain itu juga sesuai dengan teori yang disampaikan oleh Riyanto (2001) bahwa struktur aktiva adalah perbandingan atau perimbangan antara aktiva lancar dan aktiva tetap. Sehingga perusahaan yang sebagian besar dari aktivanya terdiri atas aktiva lancar akan mengutamakan kebutuhan dananya dengan utang jangka pendek. Hal ini sesuai dengan konsep perbankan yang lebih banyak mendanai operasionalnya dengan aktiva lancar atau pembayaran jangka pendek karena bank lebih menggunakan dana yang cepat likuid atau mudah dicairkan karena untuk pembiayaan operasional seperti pemberian kredit kepada para nasabah. Hasil dalam penelitian ini dapat dilihat pada struktur aktiva pada BBRI atau PT. Bank Rakyat Indonesia Tbk yang memiliki dana aktiva lancar nya lebih tinggi rata-rata sebesar 140.7025 , hal ini diikuti dengan hutang yang dimiliki PT. Bank Rakyat Indonesia Tbk sebesar 10.85748 sebagai hutang terbesar dibanding dengan bank-bank lain sedangkan aktiva lancar terendah terdapat pada BDMN atau PT. Bank Danamon Tbk dengan nilai rata-rata sebesar 43.31895, hal ini diikuti dengan hutang yang dimiliki PT. Bank Danamon Tbk sebesar 7.216867 sebagai hutang terendah dari bank-bank lain. Hasil tersebut menunjukkan bahwa antara struktur aktiva memiliki pengaruh positif signifikan karena kenaikan dari struktur aktiva diikuti oleh kenaikan hutang dari perusahaan perbankan tersebut. Dalam industri perbankan lebih mementingkan aktiva lancar dibanding dengan aktiva tetap sehingga nilai aktiva lancarnya lebih tinggi dibanding dengan aktiva tetapnya.

\section{Pengaruh Profitabilitas Terhadap Struktur Modal}

Berdasarkan hasil analisis data diketahui bahwa profitabilitas secara parsial berpengaruh terhadap struktur modal pada industri perbankan di Bursa Efek Indonesia pada tahun2005-2009. Profitabilitas adalah keuntungan atau laba yang dihasilkan perbankan dalam mejalankan operasionalnya. Pada tahun 2005-2009 Return of Asset (ROA) mengalami fluktuasi dimana pada tahun 2008 terjadi penurunan pada Return of Asset (ROA) sebesar 2,33\%. Penurunan profitabilitas yang diproksikan dengan Return of Asset (ROA) dapat disebabkan oleh dampaknya krisis global yang melanda perekonomian pada tahun 2008 sehingga berimbas pada keuntungan perusahaan. Hasil penelitian ini menunjukkan bahwa profitabilitas mempunyai pengaruh negatif signifikan terhadap struktur modal pada perbankan yang terdaftar di Bursa Efek Indonesia (BEI). Hal ini berarti bahwa semakin tinggi tingkat profitabilitas maka semakin rendah tingkat penggunaan hutang dalam struktur modal perbankan di Indonesia khususnya di Bursa Efek Indonesia (BEI) dan 
sebaliknya, semakin rendah profitabilitas pada perbankan maka semakin tinggi tingkat penggunaan hutang. Hal ini disebabkan karena perusahaan yang mempunyai profitabilitas tinggi akan mempunyai dana internal yang besar. Perusahaan akan menggunakan dana internalnya terlebih dahulu sebelum mengambil pembiayaan ekternal melalui hutang. Perusahaan akan lebih cenderung menggunakan dana internalnya karena biayanya sangat murah dibanding sumber pembiayaan ektsernal dari hutang. Karena pengunaan dana ekternal perusahaan akan dikenakan beban bunga dalam pengembaliannya namun sebaliknya, jika menggunakan dana internal tidak mengeluarkan pembayaran bunga karena diambil dari modal sendiri. Hal ini sesuai dengan Swastha (2002) yang mengatakan kelemahan dari penggunaan dana dari pihak luar (eksternal) yaitu perusahaan dikenakan beban bunga untuk hutang yang merupakan kewajiban untuk mengembalikan hutang. Jika profitabilitas perusahaan meningkat, perusahaan cenderung akan mengurangi hutang. Tingkat pengembalian yang tinggi memungkinkan perusahaan untuk membiayai sebagian besar kebutuhan pendanaan dengan dana yang dihasilkan secara internal, sehingga perusahaan tidak memerlukan sumber dana eksternal.

Hal ini sesuai dengan teori yang dikemukakan oleh Brigham dan Houston (2001) bahwa perusahaan dengan tingkat pengembalian yang tinggi atas investasi menggunakan hutang yang relatif kecil. Dan juga sesuai dengan teori struktur modal pecking order theory, yang menyatakan bahwa semakin tinggi profitabilitas perusahaan maka akan cenderung tidak menggunakan hutang untuk membiayai investasinya, namun menggunkan dana internal berupa laba ditahan. Hasil penelitian ini juga sesuai dengan penelitian Hapsari (2010) dan Amidu (2007) yang mengatakan bahwa profitabilitas berpengaruh negatif signifikan sedangkan menurut Kusuma (2005) mengatakan bahwa profitabilitas berpengaruh positif, hal ini tidak sesuai dengan penelitian yang dilakukan peneliti. Hal ini dimungkinkan karena obyek yang diteliti oleh Kusuma (2005) berbeda dengan penelitian ini, sehingga jumlah sampel juga dapat mempengaruhi perbedaan hasil penelitian.

Alasan yang menyebabkan profitabilitas mempunyai pengaruh negatif dan signifikan terhadap struktur modal, karena perusahaan dengan profit yang tinggi cenderung mendanai investasinya dengan menggunakan laba ditahan daripada pendanaan hutang. Semakin tinggi profit suatu perusahaan maka akan semakin menurun hutangnya karena semakin banyak dana internal yang tersedia untuk mendanai investasinya. Selain itu, dengan tingginya profitabilitas perusahaan maka kemungkinan kas yang ada dalam perusahaan cukup mengurangi kebutuhan untuk leverage keuangan dan keuntungan yang diperoleh perusahaan akan dikonversi menjadi dividen saham sebagai modal tambahan, keuntungan tersebut tidak dibagikan (dividen) tetapi dikapitalisasikan menjadi laba ditahan yang digunakan sebagai modal perusahaan.

Berdasarkan pengamatan pada data perusahaan perbankan, perusahaan ini merupakan perusahaan yang memiliki profitabilitas yang berfluktuatif selama periode 2005-2009. Hal ini ditunjukkan dengan naiknya Return of Asset pada tahun 2005 hingga 2007 namun pada tahun 2008 terjadi penurunan yang drastis menjadi 2,33\% 
dari laba tahun 2007 sebesar 2,60\%, penurunan ini dapat disebabkan karena krisis global yang terjadi pada tahun 2008 yang mengakibatkan keuntungan yang didapat bank pada tahun 2008 mengalami penurunan. Namun hal ini tidak direspon oleh perbankan dengan ditunjukkannya profit yang naik pada tahun 2009 sebesar 2,60\%. Tingkat keuntungan yang tinggi, dapat dilihat pada perusahaan PT Bank Rakyat Indonesia Tbk yang memiliki profitabilitas dengan rasio Return of Asset (ROA) yang tinggi pada tahun 2005 yakni sebesar 3,10\%. Apabila dilihat dari besarnya nilai rasio ROA pada perusahaan sampel, PT Bank Rakyat Indonesia Tbk merupakan perusahaan yang paling profitable, hal ini dikarenakan perusahaan tersebut mampu mengelola aset yang dimiliki dengan optimal.

\section{Pengaruh Kebijakan Dividen Terhadap Struktur Modal}

Pengaruh kebijakan dividen terhadap struktur modal pada industri perbankan di Bursa Efek Indonesia dapat diketahui dengan menggunakan uji t atau uji parsial. Kebijakan dividen merupakan pembagian laba antara pembayaran kepada pemegang saham dan investasi kembali. Laba ditahan (retained earnings) merupakan salah satu sumber dana paling penting untuk membiayai pertumbuhan perusahaan, tetapi dividen merupakan arus kas yang disisihkan untuk pemegang saham. Perusahan yang termasuk dalam sampel ini adalah perusahaan terbuka (Tbk) dalam artian perusahaan yang mempublikasikan laporan keuangannya agar dapat diketahui data keuangannya dimana masyarakat luas dapat memiliki saham perusahaan dan sebagaibahan pertimbangan dapat diketahui dari laporan keuangan perusahaan.

Dalam penelitian ini sampel yang digunakan hanya perusahaan yang membagikan dividen atau membayar dividen kepada para pemegang saham atau investor. Jadi sampel yang digunakan menjadi tujuh dari jumlah perbankan yang terdaftar di Bursa Efek Indonesia sebanyak dua puluh sembilan perusahaan karena hanya ada tujuh perusahaan perbankan yang membagikan dividen pada tahun penelitian yaitu dari tahun 2005-2009.

Hasil penelitian ini menunjukkan bahwa kebijakan dividen tidak signifikan yang berarti kebijakan dividen tidak mempunyai pengaruh terhadap struktur modal. Hasil penelitian ini sesuai dengan Nurfauziah (2007) yang mengatakan bahwa kebijakan deviden tidak berpengaruh terhadap hutang. Hal ini dimungkinkan bahwa penggunaan hutang yang tinggi akan menyebabkan pembayaran beban tetap berupa bunga, sehingga akan menyebabkan penurunan laba dan kemudian akan menyebabkan tingkat rasio dividen yang rendah. Hal ini sesuai dengan Atmaja (2008) yang menyatakan apabila dividend payout ratio tinggi maka jumlah laba bersih yang akan ditahan sebagai laba ditahan akan semakin kecil dan perusahaan akan mencari sumber dana yang berasal dari eksternal. Ketidaksignifikannya pada penelitian ini disebabkan sampel yang digunakan sedikit hanya tujuh perusahaan perbankan, karena hanya ada tujuh perusahaan perbankan yang terdaftar di Bursa Efek Indonesia (BEI) yang membagikan dividen selama lima tahun berturut-turut berdasarkan periode penelitian 2005-2009. Selain itu, ketidak signifikannya penelitian ini dapat disebabkan oleh masyarakat sebagai pihak ketiga yang akan menyimpan dananya 
berupa tabungan, giro dan deposito ke bank tidak terpengaruh oleh pembagian dividen yang dilakukan seorang manajer keuangan kepada para pemegang saham atau investor. Pada perusahaan yang telah go public seperti perbankan yang listing di Bursa efek Indonesia (BEI) ini pasti membagikan dividen bagi para investor karena hal ini merupakan nilai kredibilitas bagi perusahaan yang telah listing di Bursa Efek Indonesia (BEI) jika perusahaan tersebut tidak membagikan dividen maka dinilai perusahaan tersebut kurang baik namun hal ini tidak mempengaruhi masyarakat sebagai pihak ketiga yang sebagai deposan untuk tetap meyimpan dananya sehingga hal ini dapat sebagai bahan pertimbangan ketidak signifikannya antara kebijakan dividen dengan struktur modal.

\section{SIMPULAN DAN SARAN Simpulan}

Berdasarkan hasil analisa baik secara deskriptif maupun statistik dapat disimpulkan bahwa struktur aktiva, profitabilitas dan kebijakan dividen secara simultan memiliki pengaruh yang signifikan terhadap struktur modal pada perbankan yang terdaftar di BEI. Berpengaruhnya ketiga variabel tersebut dapat menjadikan struktur modal yang optimal bagi perbankan. Jika struktur aktiva memiliki aktiva lancar yang besar maka perbankan akan memiliki hutang yang besar pula, jika keuntungan yang diperoleh perbankan besar maka hutang akan menurun dan jika dividen yang dibayarkan manajer kepada para pemegang saham maka hutang akan menurun. Struktur aktiva berpengaruh positif terhadap struktur modal. Hal ini berarti semakin tinggi struktur aktiva maka semakin tinggi pula struktur modal, aktiva lancar yang besar akan menimbulkan hutang yang besar pula bagi perusahaan karena pada perbankan $80 \%$ pendanaan dari aktiva lancar.

Berdasarkan hasil penelitian, profitabilitas berpengaruh negatif terhadap struktur modal. Hal ini berarti semakin tinggi profitabilitas maka semakin rendah pula struktur modal, sehingga laba yang dihasilkan dari perbankan dapat membiayai asset perbankan. Kebijakan dividen tidak berpengaruh terhadap struktur modal. Dengan demikian, tinggi rendahnya kebijakan dividen tidak akan mempengaruhi struktur modal. Hal ini dapat disebabkan masyarakat sebagai pihak ketiga tidak terpengaruh oleh pembagian dividen perusahaan.

\section{Saran}

Disarankan para pelaku perusahaan perbankan untuk dapat lebih merespon atas perubahan tingkat struktur aktiva, profitabilitas dan kebijakan dividen dalam mengendalikan struktur modal di dalam perusahaan. Untuk meningkatkan nilai perusahaan, manajer keuangan harus dapat lebih mengoptimalkan nilai struktur aktiva dan profitabilitas, karena faktor tersebut adalah faktor yang berpengaruh secara signifikan terhadap struktur modal perbankan. Kebijakan dividen yang tidak berpengaruh signifikan terhadap struktur modal hendaknya lebih diperhatikan dan tidak boleh diabaikan begitu saja, dengan tidak signifikannya kebijakan dividen terhadap struktur modal maka tindakan yang harus dilakukan manajer keuangan 
adalah menjaga kestabilan pembayaran dividen tetap atau meningkatkan pembayaran dividen agar masyarakat sebagai dana pihak ketiga merasa aman dan terjamin dalam menyimpan dananya dibank tersebut. Jika faktor tersebut mampu dikelola dengan baik maka akan memberikan kontribusi besar dalam menentukan struktur modal perbankan. 


\section{DAFTAR PUSTAKA}

Amidu, Mohammed. 2007. Determinants of Capital Structure of Bank in Ghana: an empirical approach. Baltic Journal of Management, Vol. 2 Iss: 1, pp.67 - 79.

Atmaja, Lukas Setia. 2008. Teori dan Praktik Manajemen Keuangan. Andi: Yogyakarta.

Basu Swastha. 2002. Manajemen Pemasaran. Edisi Kedua. Cetakan Kedelapan. Jakarta: Penerbit Liberty.

Brigham dan Houston. 2001. Manajemen Keuangan. Edisi kedelapan. Edisi Indonesia. Buku II. Jakarta: Erlangga.

Brigham dan Houston. 2006. Dasar-Dasar Manajemen Keuangan. Alih Bahasa Ali Akbar Yulianto. Buku Satu. Edisi Sepuluh. Salemba Empat: Jakarta.

Dendawijaya, Lukman. 2003. Manajemen Perbankan. Jakarta : Ghalia Indonesia.

Gaud, dkk. 2003. The capital structure of Swiss companies: an empirical analysis using dynamic panel data. http://www.fmpm.ch/docs/6th/Papers_6/Papers_Netz/SGF686.pdf.

Hapsari Dan Mahfud. 2010. Analisis Faktor-Faktor Yang Mempengaruhi Struktur Modal Perusahaan Manufaktur Yang Terdaftar Di Bursa Efek Indonesia Periode Tahun 2006-2008 (Studi Kasus Pada Sektor Automotive And Allied Product). Skripsi. Universitas Diponegoro.

Hassa, Nurrohim KP. 2008. Pengaruh Profitabilitas, Fixed Asset Ratio, Kontrol Kepemilikan, dan Struktur Aktiva Terhadap Struktur Modal pada Perusahaan Manufaktur di Indonesia. Jurnal Sinergi. Vol. 10 No.1 Januari 2008. Hal 11 18.

Husnan. 1995. Manajemen Keuangan Teori dan Penerapan Keputusan Jangka Pendek. Badan Penerbit UGM: Yogyakarta.

Kusuma, Hadri. 2005. Size Perusahaan dan Profitabilitas : Kajian Empiris terhadap Perusahaan Manufaktur yang Terdaftar di Bursa Efek Jakarta. Jurnal Ekonomi Pembangunan: Universitas Islam Indonesia. http://journal.uii.ac.id/index.php/JEP/article/viewFile/607/533.

Nurfauziah, dkk. 2007. Analisis Hubungan Simultan antara Kepemilikan Manajerial, Risiko, Kebijakan Hutang dan Kebijakan Dividen dalam Masalah Agensi. Jurnal Sinergi. Vol. 9 No. 2, Juni 2007. Hal 157-166.

Prabansari dan Kusuma. 2005. Faktor-faktor yang Mempengaruhi Struktur Modal Perusahaan Manufaktur Go Pubic di Bursa Efek Jakarta. Jurnal Sinergi. Edisi Khusus on Finance 2005. Hal 1-15.

Riyanto Bambang. 2001. Dasar-Dasar Pembelanjaan Perusahaan. Edisi Keempat. Cetakan Ketujuh. Yogyakarta : BPFE.

Soesetio, Yuli. 2008. Kepemilikan Manajerial dan Institusional, Kebijakan Dividen, Ukuran Perusahaan, Struktur Aktiva dan Profitabilitas Terhadap Kebijakan Hutang. Jurnal Keuangan dan Perbankan. Vol .12 No.3 September 2008. Hal 384-398.

Weston, J. Fred dan Copeland. 1997. Manajemen Keuangan. Jilid 2. Alih Bahasa: A Jaka Wasana dan Kibrandoko. Binarupa Aksara: Jakarta. 